\title{
The Influence of Remembrance on Sobriety Modern Society at Café Rumi
}

\author{
Ahmed Zaranggi \\ Sekolah Tinggi Filsafat Islam (STFI) Sadra Jakarta \\ Jl. Raya Pejaten No.19, Jati Padang, Ps. Minggu, Kota Jakarta Selatan, Daerah Khusus Ibukota Jakarta 12510 \\ Email: zeranggi.reza@gmail.com
}

\begin{abstract}
The spiritual crisis is so much engulfed by the urban community with its materialistic life, this leads to a vacuum of heart and leads to serious stress and turmoil. This turmoil mobilized everyone to overcome it, including Café Rumi worshipers. A spiritual café that offers spiritual needs that are being sought by the urban community. Through the application of routine zikir rituals, it can be a solution to this problem This study aims to find out whether the typical ritual remembrance activities at Café Rumi can have a significant impact and influence on the sobriety of the pilgrims who regularly attend zikir activities that are there. This study uses qualitative methods with descriptive analysis approach through direct observation, in-depth interviews and documentation process. After that, it is done with the data analysis process, compared, described later until the final conclusions are obtained. The target of being a researcher is the Cafe Rumi congregation, most of whom are city residents. This study yields conclusions in the form of the meaning of remembrance in Café Rumi is not merely a ritual but rather a zikir in an act of sharing with others. And from the reading side there is a modification of the addition and subtraction of the number of zikir. Zikir activities are carried out in three forms, namely spiritual meditation with zikir together led by kiyai, culture through sholawatan and Sufi dances accompanied by hadrah music, and social activities in the form of sharing food to people in need at a crossroads. The ritual of the typical Sufi ritual of remembrance is also able to increase the sobriety for worshipers at Café Rumi.
\end{abstract}

Keywords: Spiritual crisis, Sufi and sobriety, Zikir

\section{INTRODUCTION}

Peace of mind is the condition expected by every human being. All human effort is aimed at the things that make him happy and peaceful. However, along with the times, the flow of modernity has colored people's lives. On the one hand, modernity has a positive impact on various technologies that facilitate various activities. As if all needs can be fulfilled in this age. However, modernity also has a negative impact. By giving birth to a materialistic, hedonic, consumptive and individualist life attitude (Rosyidi, 2006).

The negative influence of modernity is a barrier for humans to achieve peace of life. Because modernism with the spirit of materialism makes people think that matter is everything. Finally, a person's success is measured by the extent to which he succeeded in collecting money and spending it. This perspective, according to Najib Burhani, instead of making people happy and peaceful, actually makes them lose the orientation and meaning of life, isolated from themselves, and creates spiritual aridity and anxiety (Burhani, 2001).

Materialistic life occurs a lot, especially in urban areas. The city is now the center of human civilization, a storehouse of rationality, industrial areas and technology. Thus, the city was identified as the center of modernity. Thus, urban communities are at the forefront of the impact of the spiritual crisis, namely anxiety, mental disturbance and stress. As reported by the DKI Jakarta Health Office, that in the last five years mental illness visits have increased and the region with the highest number is South Jakarta (Dinas Kesehatan DKI Jakarta, 2015).

This condition of community anxiety, of course, requires an effort to overcome it. Efforts can be made in the form of therapy, meditation and religious activities such as tarekat in Sufism. A business that will have a good impact is in accordance with the tendency of modern society itself. In this case, there is a large movement of urban society towards Sufism and tarekat amid the roar of modernity, said Azumardi Azra (Bruinessen, 2008). Thus, the city community flocked to various activities that gave spiritual promises for peace of life (Burhani, 2001), such as the Majlis zikir and tarekat.

The phenomenon of urban tendency towards Sufism, according to Komaruddin Hidayat adapted by Najib, one of which is psychological escape. That is the fulfillment of spirituality through tarekat as a remedy for the psychological problems of modern society (Burhani, 2001). That is, this is in line with efforts to overcome the spiritual crisis and anxiety through the tarekat in a Sufi assembly. In addition to the spiritual thirst felt by modern society, on the other hand, there is a tendency to attend and attend the tarekat with various rituals of worship such as remembrance, sufistic studies, prayer, and Sufi dances.

Efforts to bring peace of mind in the modern era have actually been confirmed in the Koran approximately 14 centuries ago. The solution offered by this holy book is to recite to Allah SWT, then you 
will be calm. Thus, the practice of remembrance which is indeed the main worship in every congregation is able to overcome the problem of spiritual aridity and turn it into a more lively, calm and meaningful condition.

From the various groups of congregations that exist, Rumi Café is one of the zawiya that is present in the midst of modernity and the heart of the capital city. Rumi Café is a majlis of dhikr which presents various rituals that feed the soul. Rituals such as collective dhikr, Sufi studies, prayers to the Maulanā Jalāluddin Rumi Sufi dance. Zawiyah is different from the others, different because the name is unique, has Sufi rituals that display the art of music and dance, there is another social ritual in the form of sharing the food every intersection of the capital city.

Based on the above background, related to the spiritual crisis in urban areas and the tendency of the urban community towards the Sufi order, then remembrance is the solution of the Qur'an which is the main practice of each tarekat. So it is important that this study is carried out, with the hope that it can become an illustration of the rituals of Sufi remembrance and give influence and solutions to spiritual crises in urban communities through the ritual of remembrance in Rumi Café.

\section{MATERIALS AND METHODS}

This research is using literature study method. The literature study conducted by the author to search on various written sources, whether in the form of books or documents relevant to the topic of remembrance on sobriety modern society. Combine collected data, analyze, and make decisions.

\section{RESULTS AND DISCUSSION}

\section{The Essence of Zikir}

The word zikir in language is to remember what has been known before (al-hifz) (Mandzur, 1999), to maintain what is known, to present a picture of something that has been stored in the mind after sinking into the subconscious or memorizing it after being lost from memory, both through the heart or through oral, the opposite of remembrance is ghaflah (forget) (Al-Musthawafi, 1965).

Remembering something often leads the tongue to call it. Likewise, mentioning with a tongue can lead the heart to remember more about what is said. Therefore, mentioning and remembering are things that are closely related. This is the meaning of zikr in language.

In the Tasawuf Dictionary written by Solihin and Rasihin Anwar explained that remembrance is a word used to designate any form of concentration on God, remembrance is an initial principle for someone who walks towards God (sulūk) (Solihin \& Anwar, 2002). That is, by calling and remembering will focus someone on something called, in this case, God is. After knowing zikir in language, this time let's look at how the figures describe the meaning of zikr in terms. In Sufism Encyclopedia, remembrance has two meanings. First, remembrance means remembering or naming Allah by reciting good sentences. Second, feel God's presence in our hearts (UIN Syarif's author team, 2008).

In line with the above understanding, Aboebakar Atjeh interpreted zikir as a statement made with the tongue or remembering God with the heart with words that purify God (Atjeh, 1988). As for Hasan al-Banna, one of the leaders of the Muslim Brotherhood interpreted zikir as all who draw closer to Allah and all the memories that make us close to Him.

The commentators such as Makārim Syirāzi, argued that remembrance is not just saying tasbih, tahlil and takbir, but there is a heart awareness and knowledge that Allah is present and always seeing, and this is what can move a person to move, do charity, jihad and strive in kindness (Syirāzi, 2000).

In line with Syirāzi, Fakhru ar-Rāzi said that remembrance is remembrance of God both through oral, heart and limb (ar-Razi, 1999). That is, he does not only limit remembrance by just saying it, giving it a heart and what is even more real is applying it by doing good, loving and doing good deeds.

Meanwhile, Al-Ghazali called zikir as a sincere effort to divert ideas, thoughts and attention to God, so that his memory realizes that God observes all his actions and thoughts (Nakamura, 2015). In line with Quraysh Shihab, who emphasized that zikr is the awareness of the presence of Allah Almighty wherever and whenever, and the awareness of His existence with beings (Shihab, 2006).

As a figure of Orientalists who are deep in sufian's ritual, Spencer Trimingham argues that remembrance is a spiritual practice that aims to express the presence of God while imagining His form or a method to achieve spiritual concentration by referring God rhythmically and repeatedly (Trimingham, 1999). Al-Kaladzbi explained that remembrance is forgetting everything but Allah.

According to Sanerya Hendrawan, a researcher in psychology and Sufism, remembrance involves all physical and spiritual powers that are centered on Him, so that an esoteric state, peak experience, is achieved when everything is lost from the object of perception and imagination except Allah (Hendrawan, 2009).

From some of the above meanings, we can draw a common thread that includes the meaning of remembrance. That remembrance is a good blend of tongue and heart activity. Tongue speaks a special pronunciation that has the meaning of repetition, glorification and agitation, while the heart seeks to fully absorb the meaning of the speech with full awareness.

The presence of the heart must be in the activity of remembrance. Because if left unchecked, the heart will be busy with a variety of imaginations that pass. This 
condition can only be ended when the heart follows verbally in remembrance. If the one who remembers is only the tongue, while the heart is not, then the activity cannot be said as remembrance. Because it is not in accordance with the basic meaning of the word dhikr itself, namely remembering and mentioning.

The importance of the presence of the heart in remembrance because it becomes a basic element in human beings in order to establish an intimate relationship with God. Thus, if the tongue is busy chanting and purifying God, but the heart does not infiltrate at all, does not live, and does not justify the recitation of the remembrance, then practically the remembrance will be empty and dry. Remembrance like this will not have a positive impact on the culprit.

Furthermore, perfect remembrance must have two consequences. Coming out, remembrance is not just the pronunciation of the names of God, but must bring to the realization of the attributes of God through human action. That is the morality of God. Whereas inwardly, back together with something called, namely God. Being a real servant is not other than Himself.

\section{Rank of Zikir}

Remembrance is not a verbal decoration. Essential Zinc involves intuition and thought. As Ibn 'Athāillah said in Al-Hikām. It is not a reminder except when it comes to testimony (syuhūd) and contemplation (fikr) ('Athāillah, 2006). The zikir is true, while his tongue recites the best sentences, and his heart witnesses the reflections of the grace of God and meditates on the signs of his greatness.

In the message presented by Ibn 'Ath Athāillah illah, there are several levels of dhikr ('Athāillah, 2006). First, zikr is full of negligence. Some people physically do worship, but he does not really feel the presence of the Maha. His mind and heart somehow tilted, flying between the shadow of himself, his world, and the relationship between himself and his world. This remembrance does not involve the presence of the heart, only to the extent of being outward. He remembers limited speech in oral.

Second, dhikr with concentration. This remembrance rate is not easily tempted by the wild thoughts and imaginations of the perpetrators. His heart is present and his mind is focused on God. He is fully aware that he is reciting, not doing anything else. However, it still takes time and a special place to do dhikr. It has not made the whole life of his life as a dhikr.

Third, remembrance of God's appreciation and control. At this stage, dhikr had reached the level of goodness. He worshiped and did all his activities as if to see God, or he realized that God was watching him endlessly. So, he remembers without any breaks. Every activity is always solved by the conscious memory of Allah SWT.

Fourth, remembrance which negates everything other than Him. This remembrance enters the nostrils of mortality. It feels only God. At this stage everything is lost in Him, even the perpetrators of the dynasty have also disappeared. The awareness that he existed was also gone. This is the summit of dhikr in the term alGhazali, this is called al-fanā 'bi al-kulliyyāt fi Allah (total death in the presence of Allah) (Nakamura, 2015).

\section{The Essence Peace of Heart}

The language of the heart comes from Arabic, namely Qolb (قلب). Mu'jam writer Maqāyis al-Lughah said, the Qof (ق) lam (ل) and ba '(ب) are authentic original lafadz (not in the form of illat letters). Qolb has two meanings, First, is the essence and the culmination of everything. The second, in the form of a human heart, is named after the heart because it is the essence and peak of something, while the core and the noblest part of man is his heart (Ahmad bin Faris, 1979).

In its use in Arabic, Qolb means flipping, returning, going back and forth and changing (Ali, 2007). According to al-Mushthofawi in at-Tahqīq, Qolb boils down to one meaning, namely absolute change both materially and non-materially, both in time, place, nature, condition and study (Al-Musthawafi, 1965).

Such naming is thought to have something to do with the existence of the heart and its nature. The first is that the heart is the core and the center of control of all human activities. As for the second, the heart becomes the locus of good and evil. Where he often changes and turns back and forth in receiving good and evil.

Al-Ghazali, tried to explain the meaning of qalb by first making two categories. First, qalb in the physical sense, namely a lump of meat as a body organ which is located in the left part of the chest cavity and is central to blood circulation. As is well known that blood regulates all activities and brings life. The heart in this first category is the biological heart that is the object of study by doctors or health experts. Second, qalb in the sense of lathīfah rabbaniyyah rūhaniyyah 'something subtle, which has divine and spiritual nature (Al Ghazali, 1939).

If the physical has the senses born, then the spirit also has the inner senses. It is with these inner senses that we see what cannot be seen by vision born and hear what cannot be heard by birth. If the senses are born facing the material world, the inner senses face the metaphysical world.

The inner heart functions almost the same as the physical heart. The physical heart regulates the physical while the inner heart regulates the psyche. The physical heart nourishes the body by sending fresh and oxygenated blood to each cell and organ of the body. Likewise, the inner heart nourishes the soul by radiating wisdom and light (Frager, 2005).

The heart referred to in this case is not a lump of flesh in the body, but a subtle entity (lathīfah), which is the source of consciousness and the place of spiritual knowledge. Therefore someone's heart needs to be nurtured in order to make it stable and able to climb high levels of spirituality. 
The existence of the heart has a close relationship with spirit and soul, therefore, the heart is the result of the contact between spirit and soul (Hendrawan, 2009). In the sense that the soul is the psychic aspect in which the lowest is called (al-nafs al-ammārah) which distance from the spiritual. The highest is called (alnafs al-muthmainnah) which is a pure soul like clear glass without dust. Among them there is a soul who always regrets himself called (al-nafs al-lawwāmah). Whereas the reality that comes directly from God is spirit, which basically knows, acknowledges and surrenders. But if it has united with the body it can be distorted. Therefore, the spirit that has been united with the body is called the heart.

A heart that is at the stage of submission and submission is able to uncover the essence of reality as a whole because of its sharpness of vision and sensitivity. This kind of heart will also arouse the right principles, healthy mind, awareness, strong motivation, istiqomah, honesty and obedience.

In relation to this, it is necessary to develop a heart by doing rituals to cleanse the heart such as performing remembrance, worship, tafakkur, reading the Koran and avoiding inferior traits that can reduce the soul's level and dirty it so that it is not able to see reality correctly and in its entirety. Because a strong person, who has the right beliefs, a positive attitude and good behavior come from a clean heart condition.

\section{Indicator of Tranquility of the Heart}

Talking about peace of mind, there are several indicators to find out. In this case the researcher tries to look in the glasses of Sufism psychology, in order to be able to analyze precisely the object under study. Although on the other hand some personality psychology or transpersonal psychology can be used.

In The Degrees of the self, the work of Shaykh 'Abdul Khāliq al-Syabrāwi, after explaining the meaning of peace of mind, he mentions qualities that emanate from the condition of (hāl) the calm of the heart. The characteristics mentioned are Patience, Qona'ah and Zuhud (al-Syabrawi, 2015). The following is an explanation of the three characteristics or indicators of a calm heart:

\section{Patience}

The word patience comes from shabara-yashbirushabran. In terms of language, this word means holding back, tops something and rocks. According to alAsfahani in Mufradāt, the word patience means holding back difficulties. Patience is a general word that has different meanings according to the object it faces.

From the above understanding, it can be seen that the word patience means holding back or enduring something difficult, heavy and worrying. That is, this word contains the demand to endure all difficulties, both physically and spiritually.

Sayyid Mahdi explained that patience is moderate fortitude (no less and not excessive) (Sadr, 2005). Patience can also be defined as encouragement from oneself to undergo the obligations of the Shari'a, including things that must be done and things that must not be done.

\section{Qona'ah}

Qona'ah is feeling satisfied with what she has, feeling quite what she is (Sadr, 2005). This means that qona'ah is a noble trait that shows self-esteem and a standard of noble character that is owned by someone. People who are satisfied with what is in them are the richest humans in the world because true wealth is a feeling of not needing humans. The person who is qona'ah is sure that what is given to God is the best for him and full of feeling, accompanied by gratitude and abstinence.

As a hadith from the Messenger of Allah, "One who satisfies himself with what Allah has given him, is actually the richest man.

There are many influences and benefits obtained through the nature of qona'ah in one's individual life. Qona'ah provided spiritual encouragement, humility, confidence, honor and holiness. The characteristics of people who have absorbed this trait are actually happier, calmer, and softer than those who are greedy.

The feeling of being satisfied is giving awareness and sharpening spirituality, being a bull to face the future, hastening to do the charity of prayer, never complaining about what happened and encouraging someone to have many factors to achieve happiness.

\section{Zuhud}

Etymologically, zuhud comes from the word za-ha da, which in Arabic means restraint (from something which is the original law mubāh) (Baqie, 2005). At first, the suggestion of zealous adultery was motivated by the belief among these people that humans tended to enjoy too much mundane worldly things so that they were excessive in them.

Previously they thought that leaving behind worldly pleasures could maximize their spiritual potential to the fullest, whereas in other understandings, Islam never totally banned the enjoyment of the world. Indeed, if world life is positioned on the right track it will be a means to achieve happiness in the hereafter.

Imam Ja'far said, "In this world, zuhud does not mean throwing away property and rejecting what is permissible, but it means that you should not assume that whatever you have, property and power, is safer than what is beside Allah.

The hadith from Imam Ja'far provides a clear picture that zuhud in the view of Islam does not mean leaving the world of all. This means that there are two points that can be taken:

First, if you lose something, he will not dissolve in grief. But instead of ignoring that loss, he endeavors to get a glorious future and he must not waste his energy in worrying about the past. Second, regarding what he has, he must not love him too much to resemble slavery. In such a way he can maintain his freedom and freedom. 


\section{Analysis of the Effects of Remembrance and Peace of Heart}

\section{Understanding of Remembrance}

The ritual of remembrance as a way to peace of mind, this has been reported long ago by the Qur'an to mankind. The activity of remembrance by many people is understood as a means, media, and instrument to maintain awareness of Allah SWT.

Referring to the study of the theory proposed by Spencer Tirmingham, Shohib Ismail as the kiyai who led the weekly routine remembrance program also had a similar opinion. Kiyai Shohib considers that remembrance must be a priority in the journey of life.

"Remembrance for me is a means, vehicle, media, tools, instruments to build, organize and maintain mysticism in maintaining awareness with God in every breath, step, and movement both physically and mentally, in all activities.

The researcher also found the understanding that was in line with the meaning above. Like Alung who said that remembrance is a moment of meeting God to communicate and interact with consciousness. This was also revealed by Kurniawan, one of the 9-year-old pilgrims who regularly follows remembrance, he said, "Maybe if I think personally, remembrance is a method for gaining heart. Yes, the method for self-control. "That is, remembrance is understood as a method that must be maintained in God's consciousness which will produce peace of mind.

Apart from that, there is an interesting thing related to the meaning of remembrance proposed by Muhsin Mulahela, as the chairman of Rumi Café. Muhsin said that remembrance becomes a basic necessity for the soul, without remembrance like there is nothing empty, such as thirst and physical hunger. Human needs for remembrance are so fundamental. Suroso further stated that the need for remembrance is not only in the world but in life in the hereafter.

Muhsin also added that remembrance which at our stage already feels dependent on God for all our needs, God will provide his assistance. After God helps us, there is our moral responsibility to pay attention to our neighbor in need by sharing with the surrounding environment. There is an actual remembrance that is done by going out to others, not only in the person of the remembrance. This meaning of remembrance is in line with what was stated by Sheikh Nasir Makarim Shirazi.

When referred to the remembrance theory proposed by Imam Khomeni, that remembrance is a form of gratitude by remembering all the blessings of Allah, the Audit holds a view that is in line with saying, "The point is we must recite daily, if not then how is our thankfulness to Allah. Our breath, the oxygen we have breathed. God must remember that. "Grateful by realizing that everything comes from Him is also the meaning of remembrance.

From the meaning of remembrance put forward by the worshipers and the kiyai in Rumi Café, it appears that remembrance is well understood in line with some of the theories put forward by the figures. Interestingly, the concept of remembrance that is understood and carried out in this place is not just a method of mentioning the names of Allah alone, but there is a remembrance in the form of action by doing good and helping others in need around us. This is what will make the remembrance realize the presence of God and give you the heart of peace of mind.

In the end, a good understanding of zikr will certainly give a good attitude and influence for a person who remembers. That is, the level of influence of the ritual of remembrance also depends on the level of understanding possessed by the perpetrators of remembrance.

\section{Motivation for Remembrance}

Motivation in the Big Dictionary of Indonesian Language is interpreted as an impulse that can cause a person or group to be moved to do something because they want to achieve their desired goals. In other words, a person's behavior has a motive in its implementation. In this case, it will be associated with remembrance activities in Rumi Café.In observations and interviews conducted, the researchers found that the motivation of pilgrims to follow remembrance, if the red thread is taken is to seek a peace of mind. Although it has a variety of styles on how to disclose it. As Muhsin Mulahela said,

"I am interested because I live in Jakarta and do not get enlightenment and calm in the midst of busyness, competition, demands that make me easily stressed, desperate, it turns out after finding remembrance thank God that remembrance becomes my medicine."

A similar motivation was also expressed by Kurniawan and Alung, they said that remembrance as a method to achieve peace of mind, so that for both of them remembrance is a basic need for a heart that cannot be abandoned if left behind, that's where the heart will feel uneasy.

It is important to mention that Kurniawan is a person who has a dark past, meaning that before finally becoming a regular worshiper in Rumi Café, he lives an adequate life but is in anxiety, so he often takes the road to the dark world to treat it all. He is a drummer (drummer) who is reliable in a famous café in Jakarta.

On the other hand, Sharif, one of the pilgrims who studied meditation such as Yoga, Sufi Dance and so on, explained that he was interested in doing remembrance meditation because happiness is only obtained with a calm mind. He explained that the trajectory of the human mind ranges from 60-70 thousand tracks per day, remembrance makes us not subject to the many trajectories of the mind that make us nervous and uneasy.

The congregation named Chandra said that he was actually not interested in following remembrance together, but the feeling that calmed his heart was what made him eventually become Rumi Café's regular congregation. Based on the interview, he felt worried in 
the middle of his previous life he was a regular congregation of a disco place, after that he tried to get out and feel he got a prayer and even in Rumi Café wanted to prove that God actually exists or not.

It is important to mention, the Audit of one of the pilgrims who is now the vocalist of Rumi Sholawat Café group is a former rock music singer who regularly fills in classy dark cafes in Jakarta, but after feeling that everything feels empty and empty, he decides to come out and finally meet with Rumi Café which provides an intake for his soul. For him, remembrance and prayer is now a good and proper soul intake, especially as a singer group.

Bernama Adi, one of the Sufi dancers in Rumi Café, was motivated to recite, dance and take care of him because he felt that there was a certain calmness he had never felt before. He was a person who previously had a dark life, used to drinking, using drugs and so on, even though there were still tattoos all over his body. However, now he is a routine Sufi dancer and enjoys every movement and reading that is sung every dance.

Based on some of the motivations conveyed by the pilgrims, it can be seen that the remembrance performed at Rumi Café departs from achieving a state of calm, peace and happiness. Given that life in urban areas is full of pressure, competition, and the bustle of the bustle of modern society. This is what drives modern society to switch to activities that offer peace and more valuable life. Like Ahmad Najib's revelation in the book City Sufism (Burhani, 2001).

\section{The Condition of Remembrance}

In reciting ( $d z i k r$ ) certainly not only using oral to get a positive influence from this ritual. Rather, there needs to be a mind that is focused, concentrated or conscious, a solemn atmosphere and carried out in a supportive place. More than that, it is necessary to prepare the intentions and conditions that are sacred or in a state of having ablution.

Referring to the study of theory, there are several manners (adab) that need to be followed in performing the ritual of remembrance. As far as observations and interviews, researchers found that several adab had been realized in routine remembrance activities carried out by worshipers in Rumi Café. Like the place and atmosphere that supports, the obligation to have ablution 'and intention and strong motivation to get peace by remembering Him.

One of the most important factors is the awareness of remembrance. Oral words of praise, while the mind focuses on the meaning of the praise. So, the heart will be moved to remember something that is continuously recited by oral. That is, when oral and thought dhikr must be in line to get a positive influence on the heart of the remembrance.

The importance of the presence of the heart in remembrance because it becomes a basic element in human beings in order to establish an intimate relationship with God. Thus, if the tongue is busy chanting and purifying God, but the heart does not infiltrate at all, does not live, and does not justify the recitation of the remembrance, then practically the remembrance will be empty and dry. Remembrance like this will not have a positive impact on the culprit (Athaillah, 2006).

In observations and interviews, researchers found that the Rumi Café worshipers, such as Candra said that when the zikr flows, enjoy and focus on remembrance and eliminate the other thoughts. This situation is also carried out by the Audit, as the vocalist of the Rumi Café music group, in my dhikr I am silent, close my eyes, and live every reading. For him, remembrance like this will be the spirit of life as the cellphone needs to be removed. This kind of situation is also carried out by other worshipers, such as Muhsin, Alung, Kurniawan, Suroso and Syarif, who live, focus and concentrate on remembrance.

\section{Intensity of Remembrance}

Referring to the Big Indonesian Dictionary, the word intensity is defined as the state of the level or the size of the intensity in doing something. In other words, the intensity is high and low, much at least the size of a person's actions that will affect the results achieved, ending with minimum or maximum results. In this case it is related to the intensity of remembrance on the Rumi Café congregation.

In this case the noble Al-Qur'an has ordered many people to recite the dhikr, as a result, they will get the heart of hearts in making zikr. That is, the level of intensity of one's remembrance will also influence the level of impact caused by the ritual of remembrance itself. The higher the intensity of his remembrance the greater the influence, and vice versa.

Based on interviews and in-depth observations, researchers found that the phenomenon of remembrance seemed to have adhered to the environment of this congregation, this can be seen from the habit of pilgrims carrying prayer beads everywhere, the rosary is always stretched or held in his right hand. This phenomenon is always found by researchers, not infrequently also in certain conditions outside the ritual of remembrance together, they rotate the prayer beads while reciting the recitation slowly but can be seen from his mouth mumbling.

Whereas in the interview, the researchers found that the pilgrims routinely followed remembrance on Monday night, at the moment after prayer, and in each day the worshipers who were followers of the Naqsabandiyah Order had a kind of remembrance which they had to maintain, namely remembrance Khotm Khawajagan. This remembrance is proof of someone's perseverance in undergoing tarekat, meaning that they have never left remembrance of adab which is long and long enough to read.

In an interview with Muhsin, he said that remembrance is a basic need for the mind while in a day the intensity is,

"Remembrance in a day that is certain in every prayer I recite. Then the remembrance that is given like dhikr 
adab which must be done every day is approximately an hour. Besides the other remembrance."

Other congregations such as Alung who have followed the routine remembrance at Rumi Café for 4 and a half years also say the same thing, for him remembrance is a part of his life that cannot be separated. Regarding its intensity in remembrance every day he always does adab, and other remembrance. He told me that at the beginning of his remembrance or for beginners it was recommended to recite 1500 times the Lafadz of Allah in a day.

Unlike the case with Suroso, the most elderly congregation and has been doing routine remembrance for 13 years. He said, "If I can't mention it, because every breath I recite. Every time you go in and out of breath, you should make zikr. "The Jamaat, often called" Mbah Roso ", always expresses his remembrance on every breath, meaning that outside the remembrance of adab or after praying, he keeps on praying to Allah in his breath.

In addition to the remembrance that is both internal and collective, the Rumi Café congregation also performs remembrance by sharing food regularly on Fridays. This intensity of remembrance with various others is also evidence of the consistency of the pilgrims in maintaining the quality of their remembrance. Because perfect remembrance must have two consequences. Inward, reminding the remembrance of His attributes so as to comfort their hearts. Get out, that is by realizing these traits through human action (Hendrawan, 2009).

Based on the phenomena and information obtained, armed with routine monday night remembrance, and adat dhikr which is a necessity for pilgrims to take care of it every day, there is another phenomenon of carrying prayer beads always at hand, of course, the intensity of remembrance on Rumi Café worshipers is quite high. In addition, remembrance performed by sharing with others is also carried out regularly every week on Friday. This indication is enough to give the fact that the intensity of remembrance is quite optimal for the whole congregation.

\section{Circumstances After Remembrance}

Circumstances after remembrance can be known through close impact and far-reaching effects. Talking about the situation after remembrance is related to the benefits obtained by the zikr performers after routinely practicing it. Referring to the formulated theory, one of the benefits of remembrance is giving peace of mind.

In observations and personal interviews conducted, researchers found indicators of calmness of heart found in Rumi Café worshipers. As in the Sufi psychological theory put forward by 'Abdul Khāliq al-Syabrāwi, that calmness can be known through the nature of Patience, Qona'ah and Zuhud. Some of these indicators will be found through further explanation.

This can be seen through the feelings expressed by Kurniawan, worshipers who have been practicing remembrance for nine years. He said that,
"The influence was that I was an emotional person, took everything with violence. Only after I know this, it feels ashamed to just do something like that. Better to silent, calm and listen so face it more calmly."

That is, he is more patient in dealing with every problem in his life. For him, with remembrance he was better able to hold back his emotions and control himself to be more patient.

The results of patients were also felt by Alung who said that after routine recitation, had a significant impact, namely his life was calmer, calm and resigned. He told me that previously he was afraid to live because of a lot of anxiety and worry, with remembrance he slowly reduced it and lived a calm and confident life because he was sure that everything had been arranged by the Supreme Regulatory.

Besides patience, the feeling that arises is the feeling of qona'ah in living life. Candra Sugiatma felt the same feeling, she said that through routine remembrance she felt more remembered that someone always knew what she was doing, so she was more self-controlled and calm because she believed that this life had already been arranged, how she lived to live it patiently and confident.

This feeling of patience and qona'ah was also felt so deeply by Muhsin as chairman of Café Rumi who had done routine remembrance for approximately 13 years. He expressed his experience after doing zikir regularly, that with remembrance he was not anxious in facing life, easier to understand every problem, especially in remembrance he found inspiration or answers from each problem. Finally, the feeling is calm in life, easier to be grateful than to complain and demand many things.

More than that, Muhsin explained that in Rumi Café also always strives to actualize the qualities of compassion that are always mentioned in remembrance in everyday life. This can be seen from the program that is always carried out by pilgrims by issuing donations in the form of funds, services and charitable contributions made voluntarily by all worshipers in Rumi Café.

This can be seen from the food sharing program which has been held for more than 4 years by Rumi Café. Uniquely, all the needs and preparation of this sharing program come from the congregation itself, without any request for funds in the form of proposals or anything that is made and addressed to companies or community organizations.

Another indicator that appears is zuhud. That is the feeling of not being dependent and loving too much in the world. This was stated by Alung, for him having money or not having money was not a problem or according to his language, it was normal. He didn't complain much and blamed the situation for looking back and correcting himself.

The same condition was also experienced by Suroso, one of the oldest worshipers who felt that he was only dependent on Him, everything that happened like getting something or losing something was all in 
His corridor, only humans who sometimes could not accept it. For him, whatever happens, losing or getting something does not need to be too sad and happy. From this side the zuhud aspect can be seen reflected in his words and behavior.

From several statements and phenomena found, researchers see that there is an effect of remembrance for the peace of mind of the worshipers. Of the three indicators that are patient, they have the most dominant place compared to other indicators. Patience is also meant to be kind of patient in facing calamities or difficulties in life. The nature of qona'ah and zuhud is also reflected in the congregation, although at a lower level than the patient indicator.

This means that the influence of this special zawistyle Naqshbandiyah remembrance in increasing the peace of mind of the worshipers in Rumi Café has a big role. Especially in the attitude of patience in dealing with various life problems. Then at a lower level, it is easy to accept what is happening, be grateful and not easy to complain and sue, then not too dependent on what is owned in this world. Not too happy to get delicious and not too sad because of losing something.

\section{CONCLUSIONS}

Based on the findings and analysis of the data presented, the researcher can draw the conclusion that remembrance has a great influence on the lives of pilgrims in Rumi Café. By the three indicators that are patient, they have the most dominant place compared to other indicators. Patience is also meant to be kind of patient in facing calamities or difficulties in life. The nature of qona'ah and zuhud is also reflected in the congregation, although at a lower level than the patient indicator.

\section{REFERENCES}

Ahmad, Abul Husain bin Faris, Mu'jam Maqayis al-Lughah, ditahkik oleh Abdussalam Harun, Dar al-Fikr: Beirut, 1399

Al-Ghazali, Ihya' 'Ulum al-Din, Mesir: Mushthofa al-Bab al-Halabi, 1939

Ali, Yunasril, Jalan Kearifan Sufi, Jakarta: Serambi, 2002

Al-Musthafawi, Al-Tahqiq fi kalimatil qur'an al-Karim, Tehran:Markaz al-Musthafawi, 1385 HQ

Anwar, Rasihin dan Solihin, Kamus Tasawuf, Bandung: PT. Remaja Rosada Karya, 2002.

Ar-Razi, al-Fakhru, Mafatihul Ghaib, Beirut: Dar Ihya'u turats arabi, $1420 \mathrm{H}$

Athaillah, Ibnu ', Miftah Al-Falah wa Misbah Al-Arwah, diterjemahkan oleh A.Fauzy Bahseisy, Zikir Penentram Hati, Jakarta: Serambi, 2006

Atjeh, Aboebakar, Pengantar Ilmu Tarekat, Solo: Ramadhani, 1988

Bruinessen, Martin van, Urban Sufism, Jakarta: Rajawali Pers, 2008

Burhani, Ahmad Najib, Sufisme Kota, Jakarta: Serambi, 2001

Dinas Kesehatan DKI Jakarta, Profil Kesehatan Jakarta 2015, Jakarta: KAN, 2015

Frager, Robert, Heart, Self and Soul: The Sufi Psychology of Growth, diterjemahkan oleh Hasmiyah Rouf, Hati, Diri, Jiwa Psikologi untuk Transformasi Jakarta: Serambi, 2005

Ghufron, M. Nur dan Rini Risnawati S, Teori-Teori Psikologi, Yogyakarta: Ar-Ruzz Media, 2014

Hendrawan, Sanerya, Spiritual Management, Bandung: Mizan, 2009

Kaelan, Metode Penelitian Agama Kualitatif Interdisipliner, Yogyakarta: Paradigma, 2010

Mandzur, Ibnu, Lisan al-Arab, Kairo: Dar al-Hadits, 1420

Mulyati, Sri, Mengenali Tarekat-tarekat Muktabarah di Indonesia, Jakarta: Kencana, 2006

Nakamura, Kojiro, Metode Zikir dan doa Al-Ghazali, Bandung: Mizan Pustaka, 2015

Rosyidi, Dakwah Sufistik Kang Jalal, Jakarta: KPP Paramadina, 2006

Sadr, Sayyid Mahdi, The Ahlul Bayt Ethical Role Models, diterjemahkan oleh Ali bin Yahya, Mengobati Penyakit Hati, Meningkatkan Kualitas Diri, Jakarta: Pustaka Zahra, 2005

Shihab, M. Quraisy, Wawasan Al-Qur'an tentang Zikir dan Doa, Jakarta: Lentera Hati, 2006

Syirazi, Nasir Makarim, al-Amstal fi Tafsir al-Kitab al-Munzal, Qum: Madrasatu Ali bin Abi Thalib as, $1421 \mathrm{H}$

Syukur, Amin, Sufi Healing: Terapi dengan Metode Tasawuf, Jakarta: Erlangga, 2012

Syukur, M. Amin dan Fathimah Usman, Terapi Hati, Jakarta: Erlangga, 2012

Tim Penulis UIN Syarif, Ensiklopedi Tasawuf, Bandung: Angkasa, 2008Trimingham, J. Spencer, The Sufi Orders in Islam, diterjemahkan oleh Luqman Hakim, Madzhab Sufi, Bandung: Pustaka, 1999. 